\title{
Natural Radioactivity Levels in Some Milk Samples Available in Local Markets in Babylon Governorate
}

\author{
Saba Abdulzahra Obaid \\ Physics Department, Science College, University of Babylon, Babil, Iraq.
}

saaabd@yahoo.com

Submission date:- 21/3/2018 Acceptance date:- 11/2/2018 Publication date:- 3/9/2018

Keywords: Milk; radioactivity of Natural; market of Iraq ; spectroscopy of Gamma.

\begin{abstract}
The Uranium $\left({ }^{238} \mathrm{U}\right)$, Thorium $\left({ }^{232} \mathrm{Th}\right)$ and Potassium $\left({ }^{40} \mathrm{~K}\right)$ activity of specific in $(\mathrm{Bq} / \mathrm{kg})$ are measures (10) differentness types of milk which are available in market-place of Iraqi. Aspectrometry gamma ray of methodic with a $\mathrm{NaI}(\mathrm{Tl})$ detector its using for radiometric measurements. Also calculates the hazard of radiation indicates (radium equivalent activity and internally hazardous index tab) and effectiveness of Ingestion dose every sampler.

The activity of specifics in asampler of milk was varied between from $(0.274 \pm 0.158) \mathrm{Bq} / \mathrm{kg}$ to $(7.851 \pm 0.877)$ $\mathrm{Bq} / \mathrm{kg}$, for ${ }^{238} \mathrm{U}$, For ${ }^{232} \mathrm{Th}$ between from $(0.821 \pm 0.273) \mathrm{Bq} / \mathrm{kg}$ in $(3.067 \pm 0.569) \mathrm{Bq} / \mathrm{kg}$ and for ${ }^{40} \mathrm{~K}$ between (266.558 \pm 5.018$) \mathrm{Bq} / \mathrm{kg}$ to $(485.740 \pm 7.197) \mathrm{Bq} / \mathrm{kg}$. In addition to, it is finds that radium equivalent activity and internally hazard indexing to the sampler of milk ranged between (27.341) Bq/kg to (48.035) Bq/kg and from $(0.07867)$ to $(0.14720)$ respectively. So, the range summations ingestive effectiveness dose was variedly between $\left(4.861 \times 10^{-5}\right) \mathrm{Sv} / \mathrm{y}$ to $\left(1.541 \times 10^{-4}\right) \mathrm{Sv} / \mathrm{y}$. This search proves that the radioactivity of natural, hazard of radiation references and dose of effective ingestion was lower than the safekeeping, except the some value of potassium.
\end{abstract}

\section{1- Introduction}

Radionuclides, both of Uranium-238, Thorium-232, Radium-226, and Potassium-40 are enabled to enter the human body mainly through contaminated air of inhalation and contaminated water of ingestion and foodstuffs. other pathways for penetration of radionuclide into a body of humans, like the skins are irrelevant for the contexts of this search. According to their physic of different- properties of chemical, they can accumulate in the tissues of different and organs body of humans thus, representation health issues of serious for exposes workers and populations in the worldwide. In particular, their assumptions through daily intakes foods can turn out to be quite relevant to be taken into consideration. For Example, chemical Uranium-238 turn out to be primarily of toxic for the lungs and kidneys, whereas it causes damages to the proximal tubule, besides the fact that when the metal form, it has also been identified as a potential reproductive Toxicant; Thorium-232 affects lungs, liver and skeleton tissues; accumulates of Potassium in muscles and Radium is retained primarily in bones, due to metabolic similarities with Calcium. Therefor, quantities of large depositions of these radionuclides in organs of particular will be able to affecting the condition of health, through the weakening of the immun system, inducing diseases of various appearance samples, in addition to contributing to increases the rates of mortality [1].

Milk is vectoring of radionuclides of an important that humankind beings may get from the environment through the activities of mining [2]. Also, milk is one food of an important to the nutrition of human and contain every the macronutrients namely Protein, Carbohydrates, Fat, Vitamins (A, D and B groups) in addition to the particularly of trace elements Calcium, Phosphate, Magnesium, Zinc and Selenium [3]. In Iraq no surveying radioactivity of naturally in milk carries out and so far no baseline of the concentration of natural and radioisotopes of anthropogenic have been reported. So, monitoring of radioisotope activity concentrations provide with information of meaningful that can contribute to the populations of knowledge's exposure and to the setting up baselines of originality. This search been undertaken with the purpose of measuring Radioactivity of Natural to ${ }^{238} \mathrm{U}\left({ }^{226} \mathrm{Ra}\right)$, ${ }^{232} \mathrm{Th}$ and ${ }^{40} \mathrm{~K}$ in the milk of powdered sampler that are available in the Iraqi markets. Also in this study Radium activity of equivalent, hazard of internal, the absorbed rates of dose and dose of effective annual for ${ }^{238} \mathrm{U}\left({ }^{226} \mathrm{Ra}\right)$, ${ }^{232} \mathrm{Th}$ and ${ }^{40} \mathrm{~K}$ to human beings in different ages have been calculated depending on standard world equations, so as to compare them with the recommended reference limits[4]. 


\section{2- Methods and Materials}

Ten samplers of types of different to the powdered milk for infants have been collecting from the markets of local in Iraq to measure radioactivity of natural. the type samples of milk are shown in table (1), radioactivity of Natural levels has been measured using spectrometry of gamma facility, consisting multichannel of gamma analyzer equipping with a (3"×3") $\mathrm{NaI}(\mathrm{Tl})$, Figure (1):

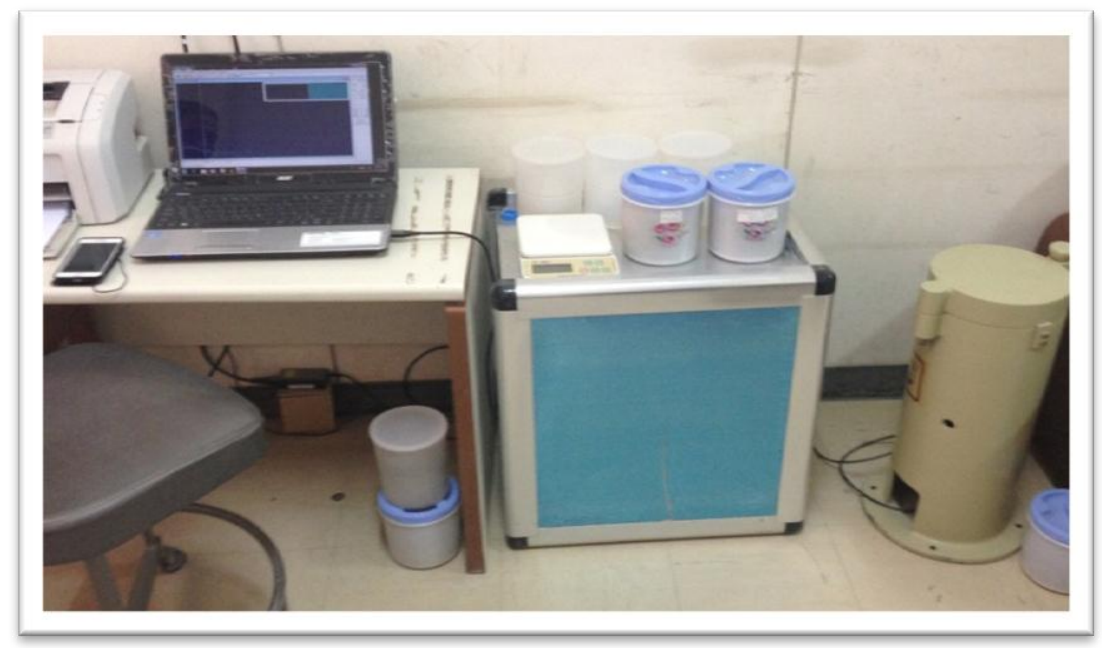

(a)

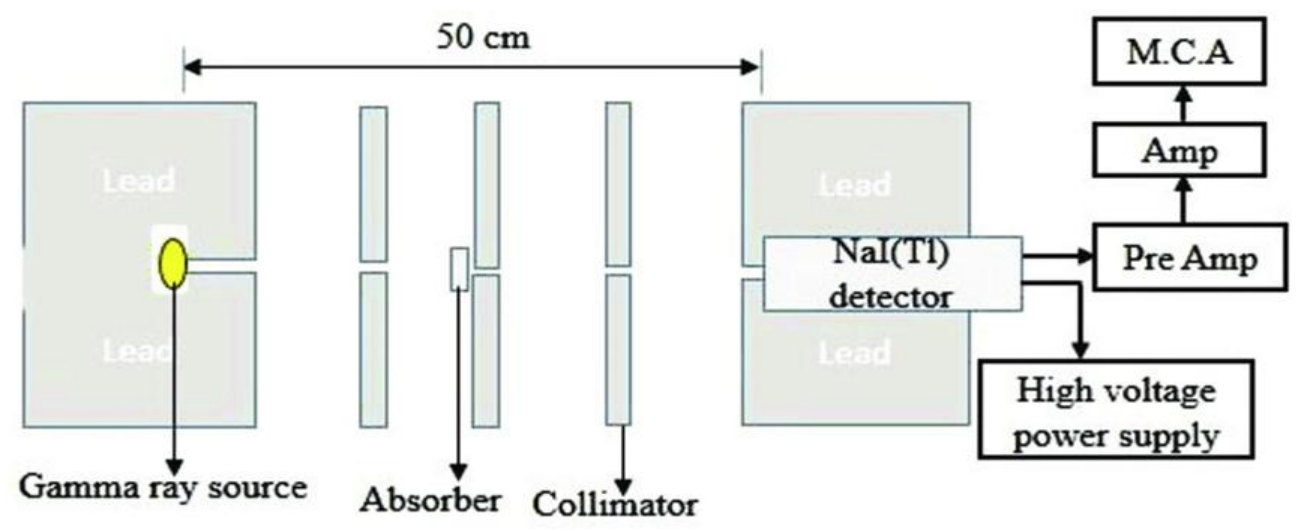

(b)

Figure 1: (a) set-up of experimentally, (b) set-up of block diagram 
Table (1): Types, origins to the samples of powdered milk.

\begin{tabular}{|c|c|c|c|}
\hline No. & Sample Code & Sample name & Country of Origin \\
\hline 1 & M1 & Golden cow's milk & Jordan \\
\hline 2 & M2 & Sponsor milk & Arab Emirates \\
\hline 3 & M3 & Surprisingly milk & New Zealand \\
\hline 4 & M4 & Anchor milk & Ireland \\
\hline 5 & M5 & Pew milk & Vietnam \\
\hline 6 & M6 & Diallak milk & Jordance \\
\hline 7 & M7 & Lancyl milk milk & Arab Emirates \\
\hline 8 & M8 & Niro milk & France \\
\hline 9 & M9 & Nktalia milk & \\
\hline 10 & M10 & & \\
\hline
\end{tabular}

\section{3- The Theoretical Part}

The spectra of gamma have been analyzed by the ORTEC Maestro-32 acquisition of data so systems of analysis. detectors have coaxially closed-facings geometric with the specification of following: resolution of calculate be $7.9 \%$ energy of $661.66 \mathrm{keV}$ of a ${ }^{137} \mathrm{Cs}$ source of standard. The efficiencies of Relative equal $1.33 \mathrm{MeV}$ for ${ }^{60} \mathrm{Co}$ were $2.2 \%$ and at $1.274 \mathrm{MeV}$ for ${ }^{22} \mathrm{Na}$ is $2.4 \%$. detectors have been shielding by lead of a cylindrical shielded until achieved lowest levels of background tab. Calibrations of energy detectors have performer with a sets standardly $\gamma$-ray $1-\mu \mathrm{Ci}$ active ${ }^{137} \mathrm{Cs},{ }^{60} \mathrm{Co},{ }^{54} \mathrm{Mn}$, and ${ }^{22} \mathrm{Na}$ source. the activities of concentration ${ }^{40} \mathrm{~K}$ have been determined directly from the peak areas when equal $1460 \mathrm{keV}$. Concentrations of activity ${ }^{238} \mathrm{U}\left({ }^{226} \mathrm{Ra}\right)$ and ${ }^{232} \mathrm{Th}$ have been calculated assuming equilibrium of secular with their products of decay. gamma of transition lines ${ }^{214} \mathrm{Bi}$ $(1765 \mathrm{keV})$ have been using to calculat radioisotopes of specific activity in the ${ }^{238} \mathrm{U}$-series, while for the ${ }^{232} \mathrm{Th}$ series the specific activities have been determined using a transition liner of gamma ${ }^{208} \mathrm{Tl}(2614 \mathrm{keV})$. time of counting every sampler has been of about $18000 \mathrm{~s}$. Since the rate of the counting proportionality amount of radioactivity contained in sampler, concentration of activities, or specific activities, $\mathrm{A}_{\mathrm{x}}$, can be evaluated in the following way [5].

$\mathrm{A}_{\mathrm{x}}=\frac{C-B G}{t \varepsilon^{0} \% M I \gamma}$.

Where: $\mathrm{A}_{\mathrm{x}}$ concentration of activities,

$\mathrm{C}$ : is the photo-peaks of area under the curve,

$\varepsilon \%$ :the energy efficiency of present,

$I \gamma$ : the present gamma-emission radionuclide of probability,

$\mathrm{X}$ : the consideration of under,

$\mathrm{t}$ : the time of counting,

M: mass of sample,

BG: background [6].

\section{4- Radium Equivalent Activity}

The most common Naturally Occurring Radioisotopes that can be found in foodstuff are represented by ${ }^{232} \mathrm{Th},{ }^{40} \mathrm{~K}$ and ${ }^{238} \mathrm{U}\left({ }^{226} \mathrm{Ra}\right)$. In order to assess the radiation doses of gamma to humankind beings due to the (internal or external) exposure to them, it is necessary to evaluate how to take properly into account their specific radioactivity. For this purpose a suitable and practical index, the so-called radium equivalent activity index Raeq has been introduced by E. I. Hamilton from the UK National Radiological Protection Board (NRPB) [7]. Ra $\mathrm{eq}_{\mathrm{eq}}$ has defined on the basis of the estimation of preliminary quantities of these radionuclides releasing the same dose of gamma ray. From the extensive review of the investigations, performed in different countries, realized by experts of a group from the Economic of Organization Co-operation of Development (OECD)'s Agency of Nuclear Energy [8] it turns out that a general agreement can be found on the statement $370 \mathrm{~Bq} / \mathrm{kg}(10 \mathrm{pCi} / \mathrm{g})$ of ${ }^{226} \mathrm{Ra}$, or $260 \mathrm{~Bq} / \mathrm{kg}(7 \mathrm{pCi} / \mathrm{g})$ of ${ }^{232} \mathrm{Th}$ or $4810 \mathrm{~Bq} / \mathrm{kg}(130 \mathrm{pCi} / \mathrm{g})$ of ${ }^{40} \mathrm{~K}$ provide similar doses of gamma ray $\{15-18\}$. Consequentially, the followings Equivalent Activity of Radium $\left(\mathrm{Ra}_{\mathrm{eq}}\right)$ of sampler in $(\mathrm{Bq} / \mathrm{kg})$ can been evaluates as $\{18-22\}$ : 
$\mathrm{Ra}_{\mathrm{eq}}=\mathrm{A}_{\mathrm{Ra}}+\left(1.43 \mathrm{~A}_{\mathrm{Th}}\right)+\left(0.077 \mathrm{~A}_{\mathrm{k}}\right)$

Where: $A_{R a}$ is the activities of specific ${ }^{226} \mathrm{Ra}$, that be usually same as that of ${ }^{238} \mathrm{U}\left({ }^{226} \mathrm{Ra}\right)$, in $(\mathrm{Bq} / \mathrm{kg}), \mathrm{A}_{\mathrm{Th}}$ is the activity of specific ${ }^{232} \mathrm{Th}$, in $(\mathrm{Bq} / \mathrm{kg})$, and $\mathrm{A}_{\mathrm{K}}$ the Activity of specific ${ }^{40} \mathrm{~K}$, in $(\mathrm{Bq} / \mathrm{kg})$. Tow Equation is based on the estimations which $10 \mathrm{~Bq} / \mathrm{kg}$ of ${ }^{226} \mathrm{Ra}$ equal $7 \mathrm{~Bq} / \mathrm{kg}$ of ${ }^{232} \mathrm{Th}$ and $130 \mathrm{~Bq} / \mathrm{kg}$ of ${ }^{40} \mathrm{~K}$ produce equalized dose of gamma. values of maximum $\mathrm{Ra}_{\mathrm{eq}}$ that been less than $370 \mathrm{~Bq} / \mathrm{kg}$ [9].

\section{5- Internal Hazard Index}

In the international scientific community there is a general consensus that regarding the human internal exposure, due ingestion or inhalation, the introduction of a specific so-called Internal Hazard Index turns out to be very suitable to assess the hazard of radiation. The index of Hazard of Internal $\left(\mathrm{H}_{\mathrm{in}}\right)$ is shown by the following expression [10]:

$$
\mathrm{H}_{\mathrm{in}}=\frac{A_{R a}}{185}+\frac{A_{T h}}{259}+\frac{A_{K}}{4810} \leq 1
$$

A consequence radiation hazard can be considered negligible if $\mathrm{H}_{\mathrm{in}}$ turns out to be smaller than one.

\section{6- Annual Effective of Dose}

Dose of annual effective due from the intakes ${ }^{238} \mathrm{U}\left({ }^{226} \mathrm{Ra}\right),{ }^{232} \mathrm{Th}$ and ${ }^{40} \mathrm{~K}$ in the foodstuffs can calculate using the formula from UNSCEAR (2000):

$\mathrm{D}=\mathrm{C} \times \mathrm{I} \times \mathrm{E}$.

Whereat:

D: Annual effective of dose (Sv/y),

C: Specific activity of radionuclides in the sampler of ingested $(\mathrm{Bq} / \mathrm{kg}), \mathrm{I}$ is powdered milk of annual intake $(\mathrm{kg} / \mathrm{y})$ that is depending on a gives Age, $\mathrm{E}$ is conversion factor dose is ingested for radionuclides ( $\mathrm{Sv} / \mathrm{Bq})$,

E: Factor of variedly conversion with both radioisotopes and ages of the individuals and is determined by ICRP (1995). The average consumption rate of milk for children, in different age groups (ages between from: 2 to $7 \mathrm{y}, 7$ to12 y, from: 12 to $17 \mathrm{y}$ ), So, adult (17 y) is $14 \mathrm{~kg} / \mathrm{y}$ and $13 \mathrm{~kg} / \mathrm{y}$, respectively [11].

\section{7- Results and Discussion}

Measuring activities of specific of ${ }^{238} \mathrm{U}\left({ }^{226} \mathrm{Ra}\right),{ }^{232} \mathrm{Th}$ and ${ }^{40} \mathrm{~K}$ detect in the sampler of milk under of powdery studying includes their uncertainly is summarized in table of contents( 2). It can be noticed that the ${ }^{238} \mathrm{U}\left({ }^{226} \mathrm{Ra}\right)$ concentrations $\mathrm{f}$ activity detected in most of samples vary between $(0.274 \pm 0.158) \mathrm{Bq} / \mathrm{kg}$ to $(6.471 \pm 0.802) \mathrm{Bq} / \mathrm{kg}$ with an average value of $(3.881 \pm 0.563) \mathrm{Bq} / \mathrm{kg}$. For ${ }^{232} \mathrm{Th}$ and ${ }^{40} \mathrm{~K}$ the measured specific activity ranged between from $(0.821 \pm 0.273) \mathrm{Bq} / \mathrm{kg}$ in $(2.125 \pm 0.443) \mathrm{Bq} / \mathrm{kg}$ with an average value of $(1.588 \pm 0.396) \mathrm{Bq} / \mathrm{kg}$ and from $(266.558 \pm 5.018) \mathrm{Bq} / \mathrm{kg}$ to $(483.595 \pm 6.984) \mathrm{Bq} / \mathrm{kg}$ with the average value $(387.187 \pm 6.299) \mathrm{Bq} / \mathrm{kg}$, respectively. And, the values of radiation hazard expressed by $\mathrm{Ra}_{\mathrm{eq}}$ and $\mathrm{H}_{\mathrm{in}}$ have been found to range from (27.341) to $(48.035) \mathrm{Bq} / \mathrm{kg}$ with an average $(35.967) \mathrm{Bq} / \mathrm{kg}$ and from: $(0.078)$ to $(0.147)$ with an average value of $(0.107)$ respectively Table 3. The Average value to the Annual Effective dose for children in different the ages group: (27)y, (7-2)y, (12-17)y and for adults (age over $17 \mathrm{y}$ ) as shown Table5: due to the intake for the three different radionuclides has resulted to be: for ${ }^{238} \mathrm{U}\left({ }^{226} \mathrm{Ra}\right): 0.337 \times 10^{-4} \mathrm{~Sv} / \mathrm{y}, 0.435 \times 10^{-4} \mathrm{~Sv} / \mathrm{y}, 0.185 \times 10^{-5} \mathrm{~Sv} / \mathrm{y}$ and $0.548 \times 10^{-}$ ${ }^{4} \mathrm{~Sv} / \mathrm{y}$; for ${ }^{232} \mathrm{Th} 0.735 \times 10^{-5} \mathrm{~Sv} / \mathrm{y}, 0.645 \times 10^{-5} \mathrm{~Sv} / \mathrm{y}, 0.556 \times 10^{-5} \mathrm{~Sv} / \mathrm{y}$ and $0.548 \times 10^{-5} \mathrm{~Sv} / \mathrm{y}$; for ${ }^{40} \mathrm{~K} 0.113 \times 10^{-3}$ $\mathrm{Sv} / \mathrm{y}, 0.704 \times 10^{-4} \mathrm{~Sv} / \mathrm{y}, 0.412 \times 10^{-4} \mathrm{~Sv} / \mathrm{y}$ and $0.360 \times 10^{-4} \mathrm{~Sv} / \mathrm{y}$ Table 4. 
Table (2): Specific avtivity (Bq/Kg) in powder milk samples

\begin{tabular}{|c|c|c|c|c|c|}
\hline \multirow[t]{2}{*}{ No. } & \multirow{2}{*}{$\begin{array}{c}\text { Sample } \\
\text { Code }\end{array}$} & \multirow[t]{2}{*}{ Sample Name } & \multicolumn{3}{|c|}{ Specific activity } \\
\hline & & & K-40 & U-238 & Th-232 \\
\hline 1 & M1 & Golden cow's milk & $319.780 \pm 6.200$ & $1.108 \pm 0.350$ & $1.800 \pm 0.499$ \\
\hline 2 & M2 & Sponsor milk & $482.829 \pm 7.227$ & $6.471 \pm 0.802$ & $3.067 \pm 0.569$ \\
\hline 3 & M3 & Surprisingly milk & $376.597 \pm 5.927$ & $5.324 \pm 0.676$ & $0.821 \pm 0.273$ \\
\hline 4 & M4 & Anchor milk & $485.740 \pm 7.197$ & $7.851 \pm 0.877$ & $0.834 \pm 0.294$ \\
\hline 5 & M5 & Pew milk & $466.497 \pm 6.813$ & $1.740 \pm 0.399$ & $0.875 \pm 0.291$ \\
\hline 6 & M6 & Diallak milk & $266.558 \pm 5.018$ & $4.782 \pm 0.644$ & $2.125 \pm 0.443$ \\
\hline 7 & M7 & Aktal Milk & $372.640 \pm 6.090$ & $0.274 \pm 0.158$ & $1.362 \pm 0.364$ \\
\hline 8 & M8 & Lancy Milk & $306.744 \pm 5.935$ & $1.796 \pm 0.435$ & $1.347 \pm 0.389$ \\
\hline 9 & M9 & Niro Milk & $310.897 \pm 5.600$ & $6.869 \pm 0.798$ & $1.479 \pm 0.382$ \\
\hline 10 & M10 & Nktalia milk & $483.595 \pm 6.984$ & $2.599 \pm 0.491$ & $2.170 \pm 0.462$ \\
\hline \multicolumn{3}{|c|}{ Average } & $387.187 \pm 6.299$ & $3.881 \pm 0.563$ & $1.588 \pm 0.396$ \\
\hline \multicolumn{3}{|c|}{ The global average } & 400 & 30 & 35 \\
\hline
\end{tabular}

Table (3): Radiation hazard in samples of power milk

\begin{tabular}{|l|c|c|c|c|}
\hline No. & Sample Code & Sample Name & $\mathbf{R a}_{\mathbf{e q}}(\mathbf{B q} \mathbf{k g})$ & Internal hazard index \\
\hline 1 & M1 & Golden cow's milk & 28.305 & 0.07942 \\
\hline 2 & M2 & Sponsor milk & 48.035 & 0.14720 \\
\hline 3 & M3 & Surprisingly milk & 35.496 & 0.11024 \\
\hline 4 & M4 & Anchor milk & 46.446 & 0.14664 \\
\hline 5 & M5 & Pew milk & 38.912 & 0.10977 \\
\hline 6 & M6 & Diallak milk & 28.355 & 0.08947 \\
\hline 7 & M7 & Aktal Milk & 30.915 & 0.08421 \\
\hline 8 & M8 & Lancy Milk & 27.341 & 0.07867 \\
\hline 9 & M9 & Niro Milk & 32.923 & 0.10748 \\
\hline 10 & M10 & Nktalia milk & 42.939 & 0.12297 \\
\hline & \multicolumn{2}{|c|}{ Average global average } & 35.967 & 1 \\
\hline
\end{tabular}


Table (4): Effective dose of average annual ${ }^{238} \mathrm{U}\left({ }^{226} \mathrm{Ra}\right),{ }^{232} \mathrm{Th}$ and ${ }^{40} \mathrm{~K}$ for children in the age groups (2-7y), $(12-17 y)$ and adults (bigger than17y).

\begin{tabular}{|l|l|l|l|l|}
\hline \multicolumn{1}{|c|}{ Code of Sample } & \multicolumn{3}{|c|}{ Annual Effective Dose (Sv/y) } \\
\cline { 2 - 5 } & \multicolumn{1}{|c|}{$\mathbf{4 0 K}$} & $\mathbf{2 3 8 U}$ & $\mathbf{2 3 2 T h}$ & Sum \\
\hline Children (2-7) y & $0.113 \times 10-3$ & $0.337 \times 10-4$ & $0.735 \times 10-5$ & $1.541 \times 10-4$ \\
\hline Children (7-12) y & $0.704 \times 10-4$ & $0.435 \times 10-4$ & $0.645 \times 10-5$ & $1.201 \times 10-4$ \\
\hline Children (12-17) y & $0.412 \times 10-4$ & $0.815 \times 10-5$ & $0.556 \times 10-5$ & $4.861 \times 10-5$ \\
\hline Adults(over 17y) & $0.360 \times 10-4$ & $0.163 \times 10-4$ & $0.548 \times 10-5$ & $5.778 \times 10-5$ \\
\hline
\end{tabular}

Table (5): The conversion factor and annual intake [12]

\begin{tabular}{|l|l|l|l|l|}
\hline \multirow{2}{*}{} & \multicolumn{2}{c|}{ Type } & \multicolumn{1}{c|}{ Th-232 } & \multicolumn{1}{c|}{$\begin{array}{c}\text { Annual } \\
\text { intake }\end{array}$} \\
\cline { 2 - 4 } & & U-238 & \multicolumn{1}{c|}{ (kg/y) } \\
\hline Powder milk (Infants $\leq 1 Y$ ) & & & & \\
\hline Powder milk (Infants $\leq 1-2 Y)$ & $4.7 \times 10^{-6}$ & $4.6 \times 10^{-6}$ & $6.2 \times 10^{-8}$ & 22.4 \\
\hline Powder milk (Children 2-7Y) & $9.6 \times 10^{-7}$ & $4.5 \times 10^{-7}$ & $4.2 \times 10^{-8}$ & 15 \\
\hline Powder milk (Children 7-12Y) & $6.2 \times 10^{-7}$ & $3.5 \times 10^{-7}$ & $2.1 \times 10^{-8}$ & 14 \\
\hline Powder milk (Children 12-17Y) & $8.0 \times 10^{-7}$ & $2.9 \times 10^{-7}$ & $1.3 \times 10^{-8}$ & 14 \\
\hline Powder milk (Adults 17Y) & $1.5 \times 10^{-7}$ & $2.5 \times 10^{-7}$ & $7.6 \times 10^{-9}$ & 14 \\
\hline
\end{tabular}

These results have been compared with the outcomes of different investigations performed in other countries. The comparison is shown in Table (6).

Table (6): Comparison of the average specific activities $(\mathrm{Bq} / \mathrm{kg})$ of ${ }^{238} \mathrm{U}\left({ }^{226} \mathrm{Ra}\right),{ }^{232} \mathrm{Th}$ and ${ }^{40} \mathrm{~K}$ in powdered milk with Data published in other countries.

\begin{tabular}{|c|c|c|c|c|}
\hline Region & ${ }^{\mathbf{2 2 6}} \mathbf{R a}$ & ${ }^{\mathbf{2 3 2}} \mathbf{T h}$ & ${ }^{\mathbf{4 0}} \mathbf{K}$ & Reference \\
\hline Egypt & $0.44 \pm 0.23$ & --- & $134.7 \pm 12$ & {$[13]$} \\
\hline Iran & ---- & --- & $37.3 \pm 3.3$ & {$[14]$} \\
\hline Jordan & 2.14 & 1.28 & 435 & {$[15]$} \\
\hline Syria & ---- & --- & 44.51 & {$[16]$} \\
\hline Sadi Arabia & 9.64 & 6.77 & $482 \pm 9.9$ & {$[17]$} \\
\hline Brazil & ---- & 3.7 & $434.1 \pm 13$ & {$[19]$} \\
\hline France & $0.05 \pm 0.01$ & $0.142 \pm 0.026$ & $387.187 \pm 6.299$ & \\
\hline Present work & $3.881 \pm 0.563$ & $1.588 \pm 0.396$ & & \\
\hline
\end{tabular}


The results obtained shown that for ${ }^{238} \mathrm{U}\left({ }^{226} \mathrm{Ra}\right)$ the average measured specific activities and their average value show to above the values reported in other countries; for ${ }^{232} \mathrm{Th}$ some values are greater and others lower. But for this two radioisotopes the results measured in Iraq turn out to be lower than the recommended reference limits by UNSCEAR (2000) [20]: $32 \mathrm{~Bq} / \mathrm{kg}$ and $45 \mathrm{~Bq} / \mathrm{kg}$ ) respectively. For what it concerns the specific activity of ${ }^{40} \mathrm{~K}$ the comparison with other outcomes shows the same behavior like for ${ }^{232} \mathrm{Th}$, but, nevertheless, the results from this study have been found to be lower than the recommended reference limit by UNSCEAR (2000): $412 \mathrm{~Bq} / \mathrm{kg}$ [20] with the only exceptions of samples M2,M4,M5 and M10. Because Potassium is a macronutrient indispensable to plants, this fact could be attributed, after a preliminary evaluation, to a local higher concentration of Potassium and hence, ${ }^{40} \mathrm{~K}$, in plants consumed by livestock in Iraq.

Equivalent activities of Radium and hazard index of internal $\left(\mathrm{H}_{\text {in }}\right)$ values for all the samples are below the value of recommended $370 \mathrm{~Bq} / \mathrm{kg}$ and one, respectively [17]. Also, it's been found that the effective dose of average annual from natural radioactivity turn out to be below the value of reference $1.0 \mathrm{mSv} / \mathrm{y}$ recommender by ICRP for All ages [21].

\section{Conclusion}

Natural radioactivity for the powdered of most available and brands of liquid milk consumed in Iraqi markets have been determined by using gamma spectroscopy. ${ }^{238} \mathrm{U}\left({ }^{226} \mathrm{Ra}\right) \mathrm{and}^{232} \mathrm{Th}$ activities have been found below the prescribed international reference levels, while some samples have ${ }^{40} \mathrm{~K}$ value which, however, have been found to be with a wide range of world as report in the literature of international scientists.

\section{CONFLICT OF INTERESTS}

There are no conflicts of interest.

\section{References}

[1] A. A.Tawalbeh, S. B.Samat, M. S. Yasir, and M.Omar, "Radiological pact of drinks intakes of naturally occurring radionuclides on adults of central zone of Malaysia", Malaysian Journal of Analytical Sciences, Vol.16, No.2, p.p187-193; 2014.

[2] IAEA, "International Atomic Energy Agency, Measurement of Radionuclides in Food and the Environment, A Guidebook", International atomic energy agency, VIENNA; 1989.

[3] UNSCEAR, "Ionizing Radiation: Sources, and Biological Effect United Nations Scientific Committee on the Effect of Atomic Radiation", United Nations: New York; 1982.

[4] FAO, "The Impact Population Growth and Urbanization on Food Consumption Patterns in Jordan" .UN, N. Y.; 1999.

[5] J.Beretka and P.Mathew," Health Phys.", Vol. 48,pp. 87-95; 1985.

[6] A.Kumar, B. Singh and S. Singh, "Radiation Measurements", Vol.36,No.1-6,pp. 465-469;2003.

[7] G. Viruthagiri and K.Ponnarasi, “Advances in Applied Science Research”, Vol.2,No. 2,pp. 103-108;2011.

[8]A. A. Abojassim Mohammed H. Al-Taweel Talib A. Abdulwahid, "Evaluation of Natural Radioactivity Levels for Local and Import of Cement in Iraq", International Journal of Scientific \&Engineering Research, Vol. 5, No.3, p. $218 ; 2015$.

[9] H. H. Al. Gazaly, Mahdi A. Bahr al-Ulum, Ali A. Al. Hamidawi, and Abdolzahra M. Al.Abbasi, "Natural radioactivity in soil at regions around the uranium mine in Abu-Skhair Najaf Province, Iraq", Advances in Applied Science Research, Vol. 5,No.1,pp.13-17; 2016.

[10] N. S. Afshari, F. Abbasisiar, P. Abdolmaleki,M. G. Nejad, "Determination of 40K concentration in milk samples consumed in Tehran-Iran and estimation of its annual effective dose",Iran.J. Radiat. Res., Vol. 7,No. 3,pp. $159-164 ; 2012$.

[11] UNSCEAR, Sources and effects of ionizing radiation. United Nations Scientific Committee on the Effects of Atomic Radiation Effects of Atomic Radiation. Report to the General Assembly with annexes. United Nations, $\mathrm{N}$. Y. 2000; 2003.

[12] S.H. Kadhim "Natural Radioactivity Levels in Some Canned Food Sample in Iraqi Markets" M.sc. Thesis university of Kufa ,Iraq;2016.

[13] I. H. Saleh, Abdelfatah. F. Hafez, Nadia.H. Elanany, Hussen. A. Motaweh, Mohammed. A. Naim, Radiological "Study of Soils, Foodstuff and Fertilizers in the Alexandria region Egypt", Turkish J. Eng. Env. Sci. Vol.31,pp.9-17;2015.

[14] N. S. Afshari, F. Abbasisiar, P. Abdolmaleki,M. G. Nejad , " Determination of ${ }^{40}$ Kconcentration in milk samples consumed in Tehran Iran and estimation of its annual effective dose,Iran".J. Radiat. Res., Vol. 7 ,No.3,pp. 159-164;2013. 
[15] A. Zaid Q., Alyassin Abdalmajeid M., Khaled Aljarrah M Ababneh Anas M., "Measurement of natural and artificial radioactivity in powdered milk consumed in Jordan and estimates of the corresponding annual effective dose", Radiation Protection Dosimetry, Vol. 138, No. 3,pp. 278 - 283 (2010) .

[16] Al-Masri M. S., Mukallati H., Al-Hamwi A., Khalili H., Hassan M., Assaf H., Amin Y.,Nashawati A.,".Natural radionuclides in Syrian diet and their daily intake", Journal of Radioanalytical and Nuclear Chemistry, Vol. 260,N. 2, pp.405-412; 2014.

[17] Z. M. Alamoudi "Assessment of Natural radionuclides in Powdered milk Consumed in Saudi Arabia and Estimates of the Corresponding annual Effective Dose" Journal of American Science,;Vol.9,No.6,pp. 267 $273 ; 2013$.

[18] Melquiades F. L., Appoloni C. R., "40K, ${ }^{137} \mathrm{Cs}$ and ${ }^{232}$ Th activities in Brazilian milk samples measured by gamma ray spectrometry", Ind. J Pure Appl. Phys Vol.40, pp.5-11;2002.

[19] Hosseni. T., Fathivand A. A., Barati H., Karimi M., " Assessment of Radionuclides in Imported Foodstuffs in Iran". Iran J. Radiat . Res.,Vol. 4,No.3 ,pp. 149 -153; 2006.

[20] UNSCEAR, Sources and effects of ionizing radiation. United Nations Scientific Committee on the Effects of Atomic Radiation Effects of Atomic Radiation. Report to the General Assembly with annexes. United Nations, N. Y.2000; 2003.

[21] ICRP, International Commission on Radiological Protection (ICRP),Age-dependent Doses to the Members of the Public from Intake of Radionuclides -Part 5 Compilation of Ingestion and Inhalation Coefficients. ICRP Publication 72; 1995.

\section{مستويات الاشعاع الطبيعية في بعض نماذج الحليب الموجودة في الاسواق المحلية في محافظة بابل}

\section{الخلاصة}

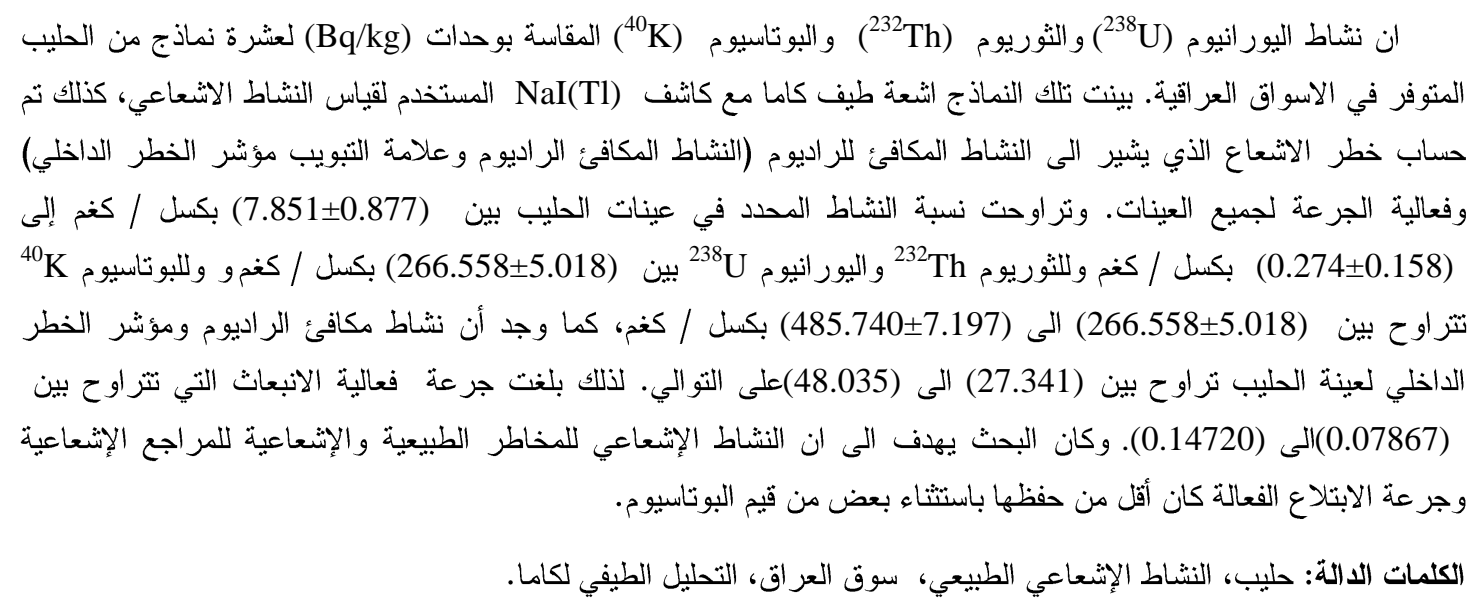

